\title{
English Teachers' Conceptions of Formative Assessment in Online Teaching
}

\author{
Wanda Listyowati ${ }^{1}$ \\ Wiyaka $^{2}$ \\ Entika Fani Prastikawati ${ }^{3}$ \\ Universitas PGRI Semarang, Indonesia \\ Email: entikafani@upgris.ac.id
}

\begin{abstract}
Formative assessment is one type of assessment that is commonly implemented in teaching and learning. However, to carry out a formative assessment, teachers need to adjust the conceptions of formative assessment in the online teaching and learning environment. This descriptive qualitative study aimed to determine the English teacher's conceptions of formative assessment in online teaching and learning. To gather the data, the writers used a closed-questionnaire and semistructured interview. Furthermore, two English teachers participated as the sample of this study. These two English teachers were selected based on several predetermined conditions; teaching experience and educational background. The result of this study shows that both English teachers have a good conception of formative assessment in online teaching. They consider that the application of formative assessments in the online classroom is easy and does not need complicated requirements in its implementation. In addition, formative assessment can help English teachers monitor the progress of their students so that they can prepare better future lesson plans according to the conditions of their students in the online teaching and learning process.
\end{abstract}

Keywords: Teachers' Conceptions; Formative Assessment; Online Teaching.

\section{INTRODUCTION}

In English language teaching and learning, teaching and assessments are two crucial things that influence each other, so that they cannot be separated (James, 2006). These two things are related to each other because the teaching and learning process is always followed by an assessment to find out the extent of students' understanding ability in receiving the subject matter (Birenbaum, 2007). Moreover, the results of assessments in education can be used as a basis for making decisions about students, the learning process, the curriculum, and educational policies. It shows that assessment plays an important role in the education field, especially in the teaching and learning process (Prastikawati, 2019).

As stated by Brown \& Abeywickrama, (2019), assessment is divided into two kinds, they are formative and summative assessment. Both of these assessments are used to evaluate the students in the teaching and learning process. According to Wiyaka et al. (2020), summative assessment is a type of assessment that is given at the end of the course and is used to measure students' understanding of the material that has been studied. In contrast with summative assessments, the formative assessment focuses more on ongoing feedback and providing benefits to students (Prastikawati et al., 2020).

In today's curriculum, formative assessment is considered one of the most influential assessments that were applied in the teaching and learning process (Widiastuti \& Saukah, 2017). This kind of assessment is performed to assess students' learning needs, understanding, and improvement in learning concerning a specific unit of learning (Karimi \& Shafiee, 2014). Moreover, Bailey \& Heritage (2008) added a critical clarification on formative assessment as the systematic process used to gather evidence and provide feedback as learning takes place.

The practice of assessment in the classroom is considered an important factor that is influenced by the teachers' conception of assessment (Arrafii, 2020). What mean by teachers' conception of assessment is "a teacher's understanding of the nature and purpose of how students' learning is examined, tested, evaluated or assessed" (G. T. L. Brown \& Gao, 2015). In 
addition, Remesal (2011) was explained that conceptions represent various types of ideas kept by teachers behind their explanations of how things in education are perceived. These statements show that teachers' conceptions of assessment especially formative assessment are important because they will influence how teachers teach and what students learn or achieve in the classroom.

Adjusting to the current conditions of the Covid19 pandemic, the Minister of Education and Culture of the Republic of Indonesia issued Circular Number 4 of 2020 concerning the implementation of education policies in an emergency for the spread of Covid19. This circular is explained that the teaching process is carried out at home through an online system. Online teaching is a teaching system that is implemented remotely by utilizing internet technology (Keengwe \& Kidd, 2010). Point to that, today's teaching process is carried out online.

In the education field, English subject is also one of the school subjects where the teaching system is implemented online (Islam, 2011). The use of an online system in teaching English can make teachers and students more independent and able to control things that cannot be done in a traditional learning system (Alhabahba \& Mahfoodh, 2016). The examples of online media that are used in the English teaching process at this time are Zoom, Google meets, Google classroom, Microsoft teams, etc. In this case, English adjusts the English teaching and assessment process.

In the online teaching process, English teachers still need to measure the students' needs, abilities, and understanding of the existing teaching and learning process Samson \& Collins (2012). This is in line with the purpose of formative assessment in English teaching and learning to forming or shaping the students during the teaching and learning process (Trumbull \& Lash, 2013). Concerning that, English teachers should have a good understanding of formative assessments to improve their quality in teaching English (Boston, 2003).
Some studies have been conducted relating to the teachers' perspective on the assessment in English teaching and learning. Laight et al (2010) investigated the conceptions and practice of formative assessment in higher education. The result revealed the participants' experiences and practices of formative assessment. The participants felt that the core of their messages can increase feedback from formative assessment results. Similarly, Widiastuti \& Saukah (2017) conducted a qualitative study by applying indepth interviews. They found that the English teachers did not follow up properly due to their low understanding of formative assessment. The teachers need more training to be able to implement formative assessments in the classroom properly. A qualitative study was also done by Guadu \& Boersma (2018). They revealed that teachers have a positive belief in the importance of formative assessment in teaching writing, and they applied it at the intermediate level.

Seeing the importance of the teachers' understanding towards formative assessment, it is potential to seek how the teachers' understanding of formative assessment in online teaching. Most of the previous studies put a big concern on English teachers in higher education. Nevertheless, studies on how the English teachers' conceptions of formative assessment in junior high school, especially in an online way have not been conducted. This study addresses the gaps from the previous studies by providing the junior high school English teachers' conceptions of formative assessment in online teaching, especially in this period of pandemic Covid19. Therefore, this study is trying to answer the following question "How are the conceptions of English teachers on formative assessment in the online teaching."

\section{METHODOLOGY}

This study was a descriptive qualitative study that asked two English teachers in SMP N 6 Semarang to participate as the sample. These English teachers were chosen for some requirements.

Table 1. The Requirements of English Teachers

Participant Sex Major Age Teachers' Degree




\begin{tabular}{|c|c|c|c|c|c|}
\hline & & of Teaching & & experience & \\
\hline Teacher A & Male & $\begin{array}{l}\text { English in Junior } \\
\text { High School }\end{array}$ & $>40$ years old & > 10 years & $\begin{array}{l}\text { Bachelor in English } \\
\text { Education }\end{array}$ \\
\hline Teacher B & Female & $\begin{array}{l}\text { English in Junior } \\
\text { High School }\end{array}$ & $>40$ years old & $>10$ years & $\begin{array}{l}\text { Bachelor in English } \\
\text { Education }\end{array}$ \\
\hline
\end{tabular}

To gather the data on the teachers' conceptions, the writers used a closedquestionnaire and a semi-structured interview. The closed-questionnaire was given before the semi-structured interview to the English teachers. The closed-questionnaire consisted of six questions relating to the implementation of formative assessment in online teaching. Those questions were adapted from Arrafii (2020). The details of the closed-questionnaire were presented in table 2 .

Table 2. The Questions of Closed-Questionnaire

\begin{tabular}{cl}
\hline No & Questions \\
\hline 1 & Formative assessment is easy to do in online teaching. \\
\hline 2 & $\begin{array}{l}\text { Implementing formative assessment in English online classes can help the English } \\
\text { teachers in getting the students' attention. }\end{array}$ \\
\hline 3 & $\begin{array}{l}\text { There are alternatives to an online formative assessment tool that the English teachers can } \\
\text { access in English class. }\end{array}$ \\
\hline 4 & $\begin{array}{l}\text { Formative assessment in online English class helps the English teachers to control the } \\
\text { students' attention. }\end{array}$ \\
\hline 5 & $\begin{array}{l}\text { Formative assessment in online English classrooms can monitor the students' language } \\
\text { progress effectively. }\end{array}$ \\
\hline 6 & $\begin{array}{l}\text { Formative assessment gives useful evidence of the students' understandings which the } \\
\text { English teachers use to plan their next lessons. }\end{array}$ \\
\hline
\end{tabular}

On the other hand, in conducting a semistructured interview, the writers allowed the participants to ask and clarify the question if they did not understand. The semi-structured interview was intended to gain the supporting data of the closed-questionnaire data.

The result of a closed-questionnaire was analyzed in percentage and presented in a graphic. Meanwhile, the data from semi-

structured interviews were analyzed, revised, transcribed verbatim, and translated into the English language to support the data from a closed questionnaire.

\section{RESULT AND DISCUSSION}

1. The English Teachers' Conceptions of Formative Assessment in Online Teaching.

The objective of this study was to investigate the conceptions that English teachers have about formative assessment in online teaching. To reach the objective, the writers give a closed-questionnaire and semi-structured interview to two English teachers of SMP 6 Semarang. The obtained data were divided into two findings; the data from closed-questionnaire and semi-structured interview. The finding revealed that English teachers have a good conception of formative assessment in online teaching.

As presented Figure 1, it presents the level of conceptions, whether it is low/medium/high. The English teachers' conceptions were divided into six conceptions; conception on the ease of implementing formative assessment in online teaching (conception 1/Q1), conception on formative assessment in helping English teachers to get students' attention (conception 2/Q2), conception on various alternatives of formative assessment (conception 3/Q3), the conception of formative assessment as a way to control students' attention (conception 4/Q4), conception on formative assessment in monitoring students' language progress (conceptions 5/Q5), and conception on the useful evidence of formative assessment in helping the English teachers plan further lessons (conception 6/Q6). 


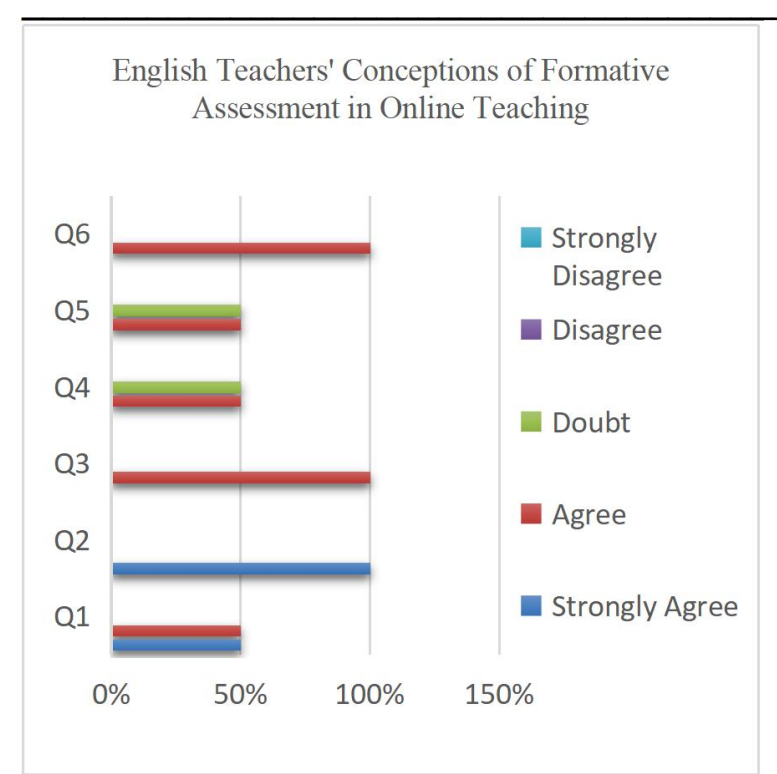

Figure 1. The Result of Closed-Questionnaire

Based on the questionnaire data (Q1-Q6) in Figure 1 shows higher results on the agree scale than on the disagree scale. In responding to the closed questionnaire (Q1-Q6) that was distributed, the English teachers gave a good response regarding the implementation of formative assessment in online classrooms. This result confirms that English teachers have a good conception regarding formative assessment in online teaching. Point to that, these findings are divided into five sections relating to research questions regarding the English teacher's conception of formative assessment in online teaching. First, the data show that formative assessments are easy to do in online classrooms. Second, implementing formative assessment in class can help teachers get students' attention. Third, there are various alternatives of formative assessment that can be used by teachers to measure students' abilities and understanding. Furthermore, in monitoring students' language development, formative assessment plays a very big role in helping English teachers in each process. Additionally, the results of the formative assessment can be used by the teacher to properly prepare further lesson plans. The details of the findings in this study are described below.

Formative Assessment as an Easy Assessment in an Online Setting Classroom.

The findings of the first data revealed the result that formative assessment is considered an easy assessment in online teaching. In this case, the English teachers can do formative assessments at the beginning, middle, or at the end of the lesson, and it doesn't take a lot of time to do formative assessments to students. Focusing on Figure 1, the results of questionnaire 1 (Q1) show a positive category. Questionnaire 1 (Q1) shows that both English teachers agree that the formative assessment is easy to do in an online classroom setting. To support these results, interview data is presented to show how the English teachers' conceptions of the ease of using formative assessments in online teaching. The writers had translated the interview transcript into English so that it will easy to be understood.

"... I don't need a specific task or instrument to do the formative assessment in the online classroom. Besides that, the implementation of the formative assessment itself is based on the things that have been mastered or still need to be learned by students. So, I think formative assessment is easy and helpful to conduct in online teaching." (Teacher A)

"Formative assessment is not difficult to do, it does not require complicated rules in its implementation so it is easy for us as English teachers to do it in the class. I usually give simple formative assessments to my students. The simple formative assessment can be in the form of words of motivation or praise for those who can answer questions or who are active in class. It is simple but meaningful for students." (Teacher B)

The interview data showed that both English teachers did not find any difficulty at all when implementing formative assessments in their class. They only need to slightly adjust the implementation of the formative assessment to the existing online teaching system.

Formative Assessment as a Help for English Teachers to Attract the Students' Attention.

After portraying the ease of using formative assessment in online teaching, the second theme highlights the formative assessment as help for English teachers to attract the students' attention. As part of the learning process, students' attention is an important thing to get in the classroom. Without the attention and focus of students, the process of transferring information 
or subject matter will not be able to run optimally. Therefore, Teacher A felt that formative assessment is able to help her in getting and monitoring the students' attention in the online classroom.

\begin{abstract}
"It is clear that students' attention is vital and must be present in teaching and learning activities. By using the formative assessment, I can get and control the students' attention in the class. I usually allocate certain points for each formative assessment activity so that students are more likely to take lessons seriously and make an effort in their learning" (Teacher A)
\end{abstract}

The results of the interview from Teacher A showed that she considered formative assessment can help teachers get the attention of their students. She allocates points in applying formative assessment so that it is able to attract students to focus and pay attention to ongoing learning.

Teacher B has a different view of formative assessment. He doubts that formative assessment is able to control students' attention in the classroom. He felt that formative assessment was less effective in gaining or controlling student attention.

"I think as the one type of assessment, formative assessment is not that effective to help me as an English teacher to get or even control my students' attention. Sometimes when I apply formative assessment in class, most of the students focus, but some students are difficult to control due to certain factors" (Teacher B)

The excerpt showed that Teacher B doubts formative assessment can help him in attracting the students' attention during the learning process. He was unsure about the benefits of formative assessment. In addition, he revealed that students' focus could be resolved by certain factors so that they did not pay attention to what their teacher explained in class.

\section{Various Alternatives of Formative Assessment.}

Based on questionnaire $3(\mathrm{Q} 3)$ in Figure 1, both English teachers agreed and they consider that there are various alternatives of formative assessment that they can access in its implementation. They did not find significant difficulty in implementing formative assessment in their online teaching.

"There are not any difficulties for me to
access the various alternatives of formative
assessment. The example of formative
assessment alternatives that I used in class is
Google Forms and Google Classrooms."
(Teacher A)

The excerpt from the interview above showed that Teacher A believed that she can access various alternatives from formative assessment easily. She also used several types of assessment forms such as Google forms and Google Classroom. The statement from Teacher $A$ is also supported by the statement from Teacher B. Teacher B also felt that it is not difficult to use or access alternatives from formative assessment.

"Well, actually there are some alternatives of formative assessment that I can access in the online teaching. Especially during this pandemic, all teaching and assessment systems are conducted online. So like it or not I also have to follow the existing conditions. Usually, English teachers here use Google Classroom to make formative assessments" (Teacher $\mathrm{B}$ added)

The result of the interview from Teacher B is almost the same as the result of the interview from Teacher A. Teacher B also used the same tools as Teacher A in conducting the formative assessment. He also stated that it is easy to access alternatives from formative assessment.

\section{Formative Assessment as a Tool to Monitor} Language Learning Progress.

As shown in Q5, it is indicated that Teacher $B$ felt doubt, and Teacher A was agreed about the positive effect of formative assessment which can help teachers to monitor their students' language progress. Teacher B argues that using formative assessment as a measure to determine students' 
language development is not enough. Meanwhile, Teacher A felt that formative assessment is a type of assessment that focused on ongoing feedback so it can help the English teachers to monitor the extent to which their students are progressing in their language skills. Here are their responses:

\begin{abstract}
"Ya, formative assessment is effective to monitor my students' language progress. Formative assessment helps me to check and control the progress of my students in learning English. Besides that, I can also find out what difficulties my students face in language learning so that I can help them overcome these difficulties for their progress." (Teacher A)

"I am a little doubtful because monitoring students' language development is not only sufficient by using formative assessments and that also depends on the extent to which students are able to master something in the classroom, and it is clear that each student is different." (Teacher B)
\end{abstract}

The interview excerpt showed a slight difference of opinion from Teacher $\mathrm{A}$ and Teacher B regarding the ability of the formative assessment tool in monitoring students' language development. Teacher A argued that the use of formative assessment can help her overcome the problems faced by her students when learning English so that indirectly formative assessment can also help her in monitoring the language development of her students. On the other hand, Teacher B assumed that each student has different capacities in learning something, especially in learning language so that they have different levels of language development from one another. Therefore, he revealed that the formative assessment was deemed insufficient to monitor the language development of each student.

Formative Assessment Result as an Evidence of the Next Teaching Plans.

According to questionnaire 6 (Q6) in Figure 1, Teacher A and Teacher B agreed that formative assessment gave useful evidence of students' understanding so that English teachers can use it to plan their next lessons. This study is in line with the study conducted by Brink \& Bartz (2017). They mentioned that formative assessment is a tool used to see and analyze whether students have achieved the expected learning outcomes and to find out whether the learning process is in accordance with the objectives, or still requires development and improvement. The following are the English teachers' responses in a semistructured interview that supports the results of the closed-questionnaire:

"........By applying the formative assessment in the online class, it helps me to know how far my students understand the material lesson I have given. From that, I can arrange the next lesson plan according to the situation and condition of my students." (Teacher A)

"Formative assessment gives me useful evidence of my students' understanding so I can use it to plan my next lesson." (Teacher $\mathrm{B}$ added)

The interview results above show that formative assessment has an important role in the planning process and improvement in the teaching and learning process. The two English teachers used the formative assessment result as a basis for them to improve and plan a good teaching plan for the future.

\section{Discussion}

This study focuses on the English teachers' conceptions of formative assessment in online teaching. The results of this study indicate that English teachers have a good conception of formative assessment in their online teaching. To find out how the two English teachers gave positive perceptions regarding the formative assessment, several points were generated to clarify it.

First, as one type of assessment, formative assessment is easy to do in class. Teachers can easily carry out formative assessments in class during learning, such as providing positive feedback to students (Havnes et al., 2012) who are able to answer teacher questions in the form of the words "Good Job!", "Good answer!" and so on. Also, the formative assessment does not require a specific task or instrument but to assist 
students during the learning process instrument (Cotton, 2017).

The formative assessment itself is beneficial for both teachers and students because its implementation is based on things that are already mastered or still need to be learned by students (Kenyon, 2019). Also, formative assessments provide students with sufficient time to obtain information and improve the skills needed during the online teaching and learning process (Wiyaka, Prastikawati, \& Adi, 2020).

Second, formative assessment is really helpful for the English teachers to get the students' attention. Students' attention to the material provided by the teacher in the English online classroom is one of the important foundations for advancing them in their learning achievement (Morrissette, 2012; Prastikawati \& Asropah, 2020). In this case, the English teachers considered formative assessment appropriate to be implemented in the classroom because it could help them get and control the attention of their students. By getting students' attention, teachers will be able to minimize existing deficiencies and maximize their teaching process in the classroom (Frunza, 2014; Kulasegaram \& Rangachari, 2018; Torrance, 2007).

Regarding the implementation of formative assessment in the English online class, of course, English teachers need to understand what alternatives or tools are used in the online formative assessment. Keeping up with current developments, technology, and situations, the average English teacher has been able to access the online formative assessment alternatives in the English class. Having the ability to access a good online formative assessment alternative will assist English teachers in providing interesting learning experiences for their students (Panero \& Aldon, 2016). Moreover, good digital formative assessment tools will lead the teachers and students to get better learning (Gaylard Baleni, 2015; Gikandi et al., 2011; Keengwe \& Kidd, 2010). Some examples of online formative assessment tools include EdPuzzle, Backchannel Chat, Plickers, Google Forms, Quizlet, and others. These kinds of online formative assessments support the process of interesting teaching and learning English as a foreign language in Indonesia.
Furthermore, the use of formative assessment in online teaching can monitor the students' language progress. This finding has been in line with the crucial objective of the formative assessment, which is to monitor student learning progress during the teaching and learning process (Herman et al., 2010; Torrance, 2007). Implementing formative assessment in online teaching presents fast and quick feedback. In this case, formative assessment will provide feedback for improving the learning program, knowing and reducing errors in the implementation of teaching and learning that need improvement (Berman, 2017).

As noted before, monitoring student language progress with formative assessment can provide information to teachers about the extent to which students have mastered language learning targets. It is also able to present data related to who needs deeper language learning, what is the next language learning target, and how the teacher classifies students for language teaching in small groups, and which students need to be observed more for learning interventions.

Moreover, formative assessment informs instruction to teachers and students during the learning process taking place in the classroom. The formative assessment confirms what knowledge students have acquired and helps better present future learning to students. This enhances learning because the instruction in the formative assessment can be adjusted as the learning progresses before the graded assessment at the end of the unit.

Further, formative assessment can help English teachers measure their students' understanding in the classroom. Similar results to this present study found by Menéndez et al. (2019) who explained that if the teacher knows the level of success of students in mastering or understanding the subject matter, the teacher can make a decision, whether a learning material needs to be repeated or not, or even improved. From these results, we can get the point that knowing the extent to which students' understanding of the subject matter in online teaching can help English teachers in designing the lesson plan that will take place at the next meeting. 


\section{CONCLUSION}

In summary, both English teachers in SMP N 6 Semarang have positive perceptions of formative assessment as one of the parts of an assessment in online teaching. The English teachers considered that the implementation of formative assessment in online classes is easy and able to help them to measure students 'understanding, control the students' attention and language progress effectively. Since this research limits the investigation on two English teachers only, further research is suggested to involve larger participants to get richer data on the English teachers' conceptions of formative assessment in online teaching.

\section{REFERENCES}

Alhabahba, M. M., \& Mahfoodh, O. H. A. (2016). The use of the internet for english language teachers' professional development in Arab countries. Australian Journal of Teacher Education, 41(4), 1-19. https://doi.org/10.14221/ajte.2016v41n4.1

Arrafii, M. A. (2020). Towards formative assessment: exploring English teachers ' conceptions and assessment in Indonesia. University of Leicester.

Bailey, A. L. \&, \& Heritage, M. (2008). Formative Assessment for Literacy. Corwin Press.

Berman, E. (2017). An exploratory sequential mixed methods approach to understanding researchers' data management practices at UVM: Integrated findings to develop research data services. Journal of EScience Librarianship, 6(1), e1104. https://doi.org/10.7191/jeslib.2017.1104

Birenbaum, M. (2007). Assessment and instruction preferences and their relationship with test anxiety and learning strategies. Higher Education, 53(6), 749-768. https://doi.org/10.1007/s10734-005-4843-4

Boston, C. (2003). The concept of formative assessment. Practical Assessment, Research and Evaluation, 8(9), 2002-2003.

Brink, M., \& Bartz, D. E. (2017). Effective use of formative assessment by high school teachers. Practical Assessment, Research and Evaluation, 22(8), 1-10.

Brown, G. T. L., \& Gao, L. (2015). Chinese teachers' conceptions of assessment for and of learning: Six competing and complementary purposes. Cogent Education, 2(1). https://doi.org/10.1080/2331186X.2014.99383 6

Brown, H. D., \& Abeywickrama, P. (2019). Language assessment, principles and classroom practices.

Cotton, D. (2017). Teachers' use of formative assessment. Delta Kappa Gamma Bulletin, 83(3), 6.

Frunza, V. (2014). Advantages and barriers of formative assessment in the teachinglearning activity. Procedia - Social and Behavioral Sciences, 114, 452-455. https://doi.org/10.1016/j.sbspro.2013.12.728

Gaylard Baleni, Z. (2015). Online formative assessment in higher education: Its pros and cons. Electronic Journal of E-Learning, 13(4), 228-236.

Gikandi, J. W., Morrow, D., \& Davis, N. E. (2011). Online formative assessment in higher education: A review of the literature. Computers and Education, 57(4), 2333-2351. https://doi.org/10.1016/j.compedu.2011.06.0 04

Guadu, Z. B., \& Boersma, E. J. (2018). EFL instructors' beliefs and practices of formative assessment in teaching writing. Journal of Language Teaching and Research, 9(1), 42. https://doi.org/10.17507/jltr.0901.06

Havnes, A., Smith, K., Dysthe, O., \& Ludvigsen, K. (2012). Formative assessment and feedback: Making learning visible. Studies in Educational Evaluation, 38(1), 21-27. https://doi.org/10.1016/j.stueduc.2012.04.001

Herman, J. L., Osmundson, E., \& Silver, D. (2010). Formative assessment practice: Measurement challenges. (CRESST Report 770), 26. http://www.cse.ucla.edu/products/reports/ R770.pdf

Islam, M. N. (2011). Independent English learning through the internet. Journal of Language Teaching and Research, 2(5), 10801085. https://doi.org/10.4304/jltr.2.5.10801085

James, M. (2006). MS of Chapter 3 in J. Gardner (Ed) (2006) Assessment and Learning (First Edition). JUNE 2006, 47-60. https://doi.org/10.13140/2.1.5090.8960

Karimi, M. N., \& Shafiee, Z. (2014). Iranian EFL 
teachers' perceptions of dynamic assessment: Exploring the role of education and length of service. Australian Journal of Teacher Education, 39(8), 143-162. https://doi.org/10.14221/ajte.2014v39n8.10

Keengwe, J., \& Kidd, T. (2010). Towards best practices in online learning and teaching in higher education. ... Journal of Online Learning and Teaching, 6(2), 533-541. http://jolt.merlot.org/vol6no2/keengwe_061 0.htm

Kenyon, B. J. (2019). Teachers' formative assessment use to check for understanding and to adjust instruction. Walden Dissertation and Doctoral Studies, February.

Kulasegaram, K., \& Rangachari, P. K. (2018). Beyond "formative": Assessments to enrich student learning. Advances in Physiology Education, 42(1), 5-14. https://doi.org/10.1152/advan.00122.2017

Laight, J., Asghar, M., \& Aslett-Bentley, A. (2010). Investigating conceptions and practice of formative assessment in higher education. Literacy Information and Computer Education Journal, 1(3), 192-199. https://doi.org/10.20533/licej.2040.2589.2010. 0027

Menéndez, I. Y. C., Napa, M. A. C., Moreira, M. L. M., \& Zambrano, G. G. V. (2019). The importance of formative assessment in the learning teaching process. International Journal of Social Sciences and Humanities, 3(2), 238-249.

https://doi.org/10.29332/ijssh.v3n2.322

Morrissette, J. (2012). Formative Assessment: Revisiting the territory from the point of view of teachersRevisiter le territoire de l'évaluation formative du point de vue d'un groupe d'enseignantes du primaire. McGill Journal of Education, 46(2), 247.

Panero, M., \& Aldon, G. (2016). How teachers evolve their formative assessment practices when digital tools are involved in the classroom. Digital Experiences in Mathematics Education, 2(1), 70-86 https://doi.org/10.1007/s40751-016-0012-x

Prastikawati, E. F. (2019). Constraints in implementing formative assessments : Teachers' voice toward the principle of assessment for learning. 1937(October), 329335.
Prastikawati, E. F., \& Asropah, A. (2020). Students' perception toward spada upgris as digital platform in learning process. Refleksi Edukatika: Jurnal Ilmiah Kependidikan, 11(1), 49-58. https://doi.org/10.24176/re.v11i1.4768

Prastikawati, E. F., Wiyaka, W., \& Adi, A. P. K. (2020). Online backchannel as a formative assessment in improving writing skills. Journal on English as a Foreign Language, 10(2), 359-384. https://doi.org/10.23971/jefl.v10i2.2044

Remesal, A. (2011). Primary and secondary teachers' conceptions of assessment: A qualitative study. Teaching and Teacher Education, 27(2), 472-482. https://doi.org/10.1016/j.tate.2010.09.017

Samson, J. F., \& Collins, B. A. (2012). Preparing all teachers to meet the needs of English language learners applying research to policy and practice for teacher effectiveness. April. www.americanprogress.org

Torrance, H. (2007). Assessment as learning? How the use of explicit learning objectives, assessment criteria and feedback in postsecondary education and training can come to dominate learning. Assessment in Education: Principles, Policy and Practice, 14(3), 281-294. https://doi.org/10.1080/09695940701591867

Trumbull, E., \& Lash, A. (2013). Understanding formative assessment: insights from learning theory and measurement theory. San Francisco: WestEd., April, 1-20. https://www.wested.org/online_pubs/resou rce1307.pdf

Widiastuti, I. A. M. S., \& Saukah, A. (n.d.). Formative assessment in EFL classroom practices. In journal2.um.ac.id. Retrieved February 20, 2021, from http://journal2.um.ac.id/index.php/jbs/articl e/view/677

Wiyaka, Prastikawati, E. F., \& Adi, A. P. K. (2020). Backchannel as an online HOTS-based formative assessment to improve students' reading skills. 417(Icesre 2019), 95-100. https://doi.org/10.2991/assehr.k.200318.018

Wiyaka, W., Prastikawati, E. F., \& Kusumo Adi, A. P. (2020). Higher-Order Thinking Skills (HOTS)-based formative assessment: A proposed model for language learning 
LANGUAGE CIRCLE: Journal of Language and Literature, 16(1) October 2021

assessment. Vision: Journal for Language and

https://doi.org/10.21580/vjv9i25859

Foreign Language Learning, 9(2), 115. 